\title{
The Influence of Public Service Motivation on Service Quality of Civil Servants \\ in West Sumatra Indonesia
}

\author{
Syamsir \\ Senior Lecturer of Padang State University, West Sumatra Indonesia;
}

\begin{abstract}
Background - Most of PSM studies tend to conclude that PSM cases and theories are cross-culturally viable. Besides, so far, most PSM research focuses more on employees (public and private) in the Western and developed countries; and almost no study of the PSM in developing countries. In addition, most of the PSM theories tended to generalize the assumptions of the PSM among employees and often ignore cultural dimensions in their analysis, including in relation to the effect of PSM on the quality of work. Purpose - The purpose of this study was to find out the influence of Public Service Motivation (PSM) on service quality of civil servants in a wide range of government agencies in the province of West Sumatra. Design/methodology/approach - This study used quantitative methods. Data were collected through proportional stratified random sampling from a sample consisted of 1,270 respondents from some government institutions in West Sumatra province. Data were analyzed with multiple regression analysis. Finding - The finding of this study indicated that the overall public service motivation significantly influenced on the service quality of civil servants in a wide range of government agencies in West Sumatra province. Besides, the results of this study also indicated that the PSM dimension associated with commitment to public interest have a greater influence than the other dimensions of PSM, namely attraction to public policy making, compassion, and self sacrifice. Practical Implications - This study would be offering a consideration and advice to the local government about the need to consider the aspects of public service motivation in improving the service quality of civil servants, especially in West Sumatra Indonesia.
\end{abstract}

Keywords : Public Service Motivation (PSM), service quality, civil servants

\section{Introduction}

The study of Public Service Motivation (PSM) has become one of the most popular studies in public administration in more than three decades. In addition, PSM is still a new concept and theory that need to be tested with more research findings. The earliest investigation of PSM was conducted in 1982 by Hal G. Rainey, when he tried to measure PSM by asking public and private sector managers about their desire to participate in "meaningful public service" (Brewer and Selden, 1998).

PSM has often defined as 'an individual's predisposition to respond to motives grounded primarily or uniquely in public institutions and organizations' (Perry and Wise, 1990). In their definition, Perry and Wise thus focused on the unique features of government that might drive individuals. Based on rational, norm-based and affective ground, Perry (1996) found four dimensions of PSM: attraction to policy making, commitment to the public interest and civic duty, compassion, and self-sacrifice. On the other side, Brewer and Selden (1998) have defined PSM as 'the motivating force that makes individuals deliver significant public service'. While Rainey and Steinbauer (1999) define PSM as a 'general altruistic motivation to serve the interests of a community of people, a state, a nation or humanity'. Crewson (1995) also defined the PSM as an individual service orientation that is useful for society, the orientation of helping others, and the feeling of accomplishment as intrinsic or service orientation.

From these definitions, it could be understood that PSM is a characteristic or special features and should be manifested among public servants. But, on the other side, it does not mean that PSM is only belonging to public servants. PSM is also very likely found among the employees of the private sector or other sectors. Many studies in developed countries have shown that individuals with greater public service motivation (PSM) values are more likely to work for government (Perry and Wise, 1990; Ertas, 2014), because government jobs offer more public service opportunities. The question then arises 
of whether they are also give well performance and good quality service to citizen. Based on his study on the relationship between employment in the government sector and self-reported volunteering in organization, Ertas (2014) found that government employees engage in significantly more volunteering than their private-sector counterparts. It means that employees with greater public service motivation values are more likely to be volunteering thus they are more likely to perform and address good service to citizens.

Based on their study related to extrinsic motivation, PSM and labour market characteristics in a multilevel model of public sector employment preference in 26 countries, Van De Walle, Steijn, and Jilke (2015) found that on the individual level, public service motivation and extrinsic motivation are both important drivers for this preference. Intrinsic motivation, in turn, is negatively related to people's inclination to work for the public sector. Working for the public sector is seen as a good and safe career option. In countries with a career-rather than position-based system of public employment, people are more likely to prefer public employment. The findings reveal that public service motivation (helping other people, being useful to society) and extrinsic motives (job security, a high income, opportunities for advancement) play an important role in this preference.

Many studies on PSM generally assumed that PSM have a positive effect on job performance (Perry and Wise, 1990; Schott, Van Kleef, and Steen, 2015; Van Loon, 2015; Taylor, 2011). It means that PSM also influenced on the service quality of employees, including civil servants. In addition, numerous studies have shown that public service motivation (PSM) is positively associated with public sector employment (Kjeldsen and Jacobsen, 2013). Besides, Rose (2013) also argued that public service motivation (PSM) research has demonstrated the association of PSM with interest in government and nonprofit careers.

According to studies that have been conducted in some developed countries, PSM were found to have significant influences and correlations with job performance, service quality, and the success of employees or organizations to achieve their objectives. Some researchers have put their attention and look at the importance of studies on PSM. However, the studies so far were more conducted in the developed countries, both in Western and other developed countries. Perry and Wise (1990), for instance, found that public service motivation is positively related to individual performance in public organizations. However, the research finding among public servants in the developed countries certainly can not be generalized to the case and the PSM among the public servants in other countries, especially the third world country like Indonesia, where the context of the countries and the characteristics of the employees might be different compared to those in the West or developed countries in terms of demographic conditions, culture, religious (belief), etc.

This paper will try to analyze the influence of public service motivation on service quality of public servants in West Sumatra, Indonesia. Then the main research question of this study can be summarized as: Is there a significant influence of PSM on service quality of civil servants in West Sumatra? This study was conducted in 2014 in collaboration with and supported by General Directorate of Higher Education, the Ministery of National Education of Indonesia.

\section{The Literature Study and Concept of Public Service Motivation (PSM)}

In the last three decades, study about PSM and related constructs in other fields has grown significantly. In a subsequent analysis of PSM and government effectiveness, Rainey and Steinbauer (1999), for instance, offered a more general definition of PSM. They associated the construct with altruism in referring to PSM as a "general, altruistic motivation to serve the interests of a community of people, a state, a nation or humankind". The Rainey and Steinbauer definition is similar to that of Brewer and Selden (1998), who defined the concept of PSM as "the motivational force that induces individuals to perform meaningful public, community, and social service". Brewer and Selden emphasize its behavioral implications and applicability beyond the public sector.

The most recent variation of the definition within public administration emanates from research in Europe by Vandenabeele (2007), who defined PSM as "the beliefs, values and attitudes that go beyond self-interest and organizational interest, that concern the interest of a larger political entity and that motivate individuals to act accordingly whenever appropriate". Beside, PSM can also be broadly defined as the beliefs, values, and attitudes that go beyond self-interest and organizational interest to energize employees to do good for others and contribute to the well-being of organizations and society (Perry and Hondeghem 2008).

However, the most commonly cited definition of public service motivation (PSM) literature is credited to James L. Perry and Lois R. Wise that defines PSM as "an individual's predisposition to respond to motives grounded primarily or uniquely in public institutions and organizations." In their definition, Perry and Wise thus focused on the unique features of government 
that might drive individuals. Building on Rainey's work, Perry and Wise (1990) identified three bases of PSM: rational, normbased, and affective. First, rational motives are grounded in individual utility maximization, and they are operative when individuals want to participate in the policy process, are committed to a public program because of personal identification with it, and serve as advocates for a special or private interest. Second, norm-based motives are grounded in a desire to pursue the common good and further the public interest, however one perceives it. These motives include patriotism, duty, and loyalty to the government. Third, affective motives are grounded in human emotion, and they are characterized by a desire and willingness to help others.

After establishing this theoretical framework, Perry and Wise (1990) formulated three propositions: 1) The greater an individual's PSM, the more likely it is that the individual will seek membership in a public organization. 2) In public organizations, PSM is positively related to performance. 3) Public organizations that attract members with high levels of PSM are likely to be less dependent on utilitarian incentives to manage individual performance effectively.

In addition to valuing intrinsic rewards over extrinsic ones, public service motivation suggests that public employees or civil servants are more likely than private sector employees to possess attitudes that are other directed. While other studies found that civil servants (public employees) to be more altruistic (Rainey 1997), supportive of democratic values (Blair and Garand 1995), and committed to civic duty (Conway 2000) than private sector employees. For these reasons, Brewer (2003) concludes that civil servants are motivated by a strong desire to perform public, community, and social services. This also means that quality service of civil servants should be assumed to be influenced by PSM level of the civil servants.

Public service motivation (PSM) is one the most important ideas introduced into the field of public administration within the last three decades. Scholars have characterized PSM in many different ways, such as a service ethic, calling, or altruistic aims that motivate individuals to serve the public interest, help others, and be useful to society (Leonard Bright, 2011). Some scholars have also argued that people with high levels of these characteristics are good employees in public organizations.

Based on their study in North Caroline, USA, Clerkin and Coggburn (2012) found that PSM is a moderate indicator of an individual's sector preference. It means that as PSM increases, the attractiveness of working also increases; and, finally it is expected that the service quality of the individuals in the work also increases. Focusing on a pre-service sample of undergraduate students allows them to conclude that PSM is a need people have prior to entering the workplace, and it may indeed drive whether an individual works in the government, nonprofit, or for-profit sector.

The theory of PSM is generally used to suggest that individuals with greater PSM are more likely (1) to be found working in government because of the opportunities it offers to provide meaningful public service, and (2) to perform better in - and feel more satisfied with - their public sector jobs because they find this type of work intrinsically rewarding. Based on this proposition, one of the fundamental assumptions in PSM research is that individuals with greater PSM are more likely to work in government because of the opportunities it offers to provide meaningful public service (Bradley E. Wright and Adam M. Grant. 2010). This assumption is supported by a growing body of empirical research that has found PSM to be higher among public sector employees than among private sector employees. Unfortunately, the evidence for the second part of the assumption, focusing on the cause of these differences, is largely circumstantial. While public employees may have higher PSM because the work of government agencies attracts individuals with those values, the differences may also be a result of organizational environments that cultivate those values in their employees over time (Pandey and Stazyk, 2008; Moynihan and Pandey, 2007).

\section{Determinants for Service Quality}

Service quality is often and generally defined as a comparison of expectations about a service with performance. Service quality can also be simply defined as an achievement in customer service. In general, customers or citizens compare perceived service with expected service in which if the former falls short of the latter the customers are disappointed. Service quality could be related to service potential (such as, worker's qualifications); service process (such as, the quickness of service) and service result (that is, customer satisfaction). A public service with high service quality will meet customer or citizen needs and improved service quality may increase the trust of citizens to civil servants.

Parasuraman et al. (1988) have defined service quality as the ability of the organization to meet or exceed customer expectations. Service quality can also be defined as an overall judgment similar to attitude towards the service and generally accepted as an antecedent of overall customer satisfaction (Zeithaml and Bitner, 1996). There is usually the difference between customer expectations of service and perceived service. Perceived service quality results from comparisons by 
customers of expectations with their perceptions of service delivered by the suppliers. If expectations are greater than performance, then perceived quality is less than satisfactory and hence customer dissatisfaction occurs (Parasuraman et al., 1985; Lewis and Mitchell, 1990).

In their previous studies on a conceptual model of service quality and its implications for future research, Parasuraman, Zeithaml, and Berry (1985) proposed three themes on service quality, that is: 1) Difficult and complicated to evaluate as compared to tangible goods quality; 2) Service quality perception results from actual service performance vs consumer expectations, and 3) Quality evaluation not solely focuses on outcome of service. But also involves the evaluation of service delivery process.

Service quality in various service activities has gain a lot of attention from researches and practitioners. The origins of numerous instruments measuring service quality can be traced back the pioneering work of Parasuraman and his colleagues. Zeithaml, Parasuraman, and Berry (1990) described that there are ten determinants that may influence a service quality, as they described in the SERVQUAL model, that is: reliability, responsiveness, competence, access, courtesy, communication, credibility, security, understanding the customer and tangibles. These determinants were later reduced to five, that is: tangibles; reliability; responsiveness; service assurance, and empathy (so called as RATER model). Reliability means the ability to perform the promised service dependably and accurately; Assurance referred to the knowledge and courtesy of employees and their ability to convey trust and confidence; Tangibles means the appearance of physical facilities, equipment, personnel and communication materials; Empathy, that is the provision of caring, individualized attention to customers, and Responsiveness referred to the willingness to help customers and to provide prompt service.

The simplified RATER model allows customer service experiences to be explored and assessed quantitatively and has been used widely by service delivery organizations. Nyeck, Morales, Ladhari, and Pons (2002) stated the SERVQUAL measuring tool appears to remain the most complete attempt to conceptualize and measure service quality. The SERVQUAL measuring tool has been used by several researchers to examine numerous service industries such as healthcare, banking, financial services, and education. Nevertheless, based on some considerations, the current study have referred the concept of service quality to the opinion of Dwiyanto, et.al. (2002). Dwiyanto et.al. described that there are eight indicators to measure (or influence) the service quality among civil servants in Indonesia, that is: 1) Immediacy in the delivery of services; 2) Timeliness of services; 3 ) Ease in the service process; 4) Funding reasonable in the service process; 5) easiness in communication access; 6 ) Readiness of employees if necessary; 7) Justice in providing services; and 8) public satisfaction with the service.

\section{Public Service Motivation and Service Quality}

The generally assumption underlying the research on public service motivation is that individuals working in government demonstrate a commitment to the public interest, a desire to serve others, and self-sacrifice (Houston 20006). Hence, issues regarding PSM (and work motivation in general) have generated particular interest because they are assumed to have a positive influence on job satisfaction and fulfilment; and appear to have a positive impact on the job behaviour of individuals and their respective level of performance (Emanuel Camilleri, 2007). Thus, it is also assumed that the PSM influence the quality of service among employees. Besides, one of three PSM propositions formulated by Perry and Wise (1990) stated that in public organizations, public sector motivation is positively related to performance. This proposition means that PSM is assumed to have positive influence on service quality of a civil servant.

Van Loon, Vandenabeele, and Leisink (2015) argued that a core proposition of public service motivation (PSM) theory is that PSM is positively related to individual performance. The PSM-performance relationship may be more complex than previously envisioned, as both type of performance and person-job fit matter. On the other side, public service as a calling leads civil servants to share knowledge in order to create more advanced organizational knowledge and accordingly improve public service performance (Chen and Hsieh, 2015). Generally, in public institution, public sector managers want to attract employees with high public service motivation as they are expected to perform better (Andersen, 2012).

Many literature of public service motivation expects public service motivation (PSM) to affect performance, but most of the existing studies of this relationship use subjective performance data and focus on output rather than outcome (Andersen, Heinesen, and Pedersen (2014). On the other side, most of motivation scholars have argued that intrinsic motivation is an important driver of employee attitudes (Cho and Perry, 2012). Based on this, it is expected that with higher level of public 
service motitavtion, civil servants will perform better in their task to serve citizens. Thus, it is also assumed that the PSM influence the quality of service among civil servants.

Steijn (2008) found that PSM's effect on public employee job satisfaction and intention to stay in their jobs was stronger when employees felt that their work was useful to society. In addition, Van Loon (2015) argued that empirical studies have found a positive relationship between public service motivation (PSM) and individual performance. However, it is uncertain whether PSM inspires similar behaviors among employees in different contexts. In addition, based on their study in Denmark, Andersen, Heinesen, and Pedersen (2014) investigated the association between PSM and the performance of Danish teachers using an objective outcome measure. Based on the study they found that PSM is positively associated with examination marks. The result indicated that PSM may be relevant for performance (service quality) improvements.

Beyond job reward motivators, PSM suggests that public employees are more likely than private employees to possess attitudes that are "other directed." Consistent with this expectation, Brewer (2003) finds that public employees score higher on attitudinal items related to social trust, altruism, equality, tolerance, and humanitarianism. Other studies have found public employees to possess more altruistic attitudes than private sector workers (Rainey 1997), be more supportive of democratic values (Blair and Garand, 1995), and possess a higher sense of civic duty (Conway, 2000). Based on these findings Brewer (2003) concludes that public servants "are motivated by a strong desire to perform public, community, and social service". As a result, based on this proposition, it is expected that PSM will have a significant influence on service quality of an employee, especially civil servants.

\section{Research Methods}

This study used quantitative approach. The data upon which this paper is based were collected in a survey among civil servants from some government institutions in West Sumatera, Indonesia. Data in this study were collected through questionnaires distributed to respondents from some regency government institutions in West Sumatera.

As stated before, public service motivation consists of a number of dimensions. However, in order to limit the analyses, this paper only considers an aggregate instrument of PSM. This instrument involves averaging the score on a the set of PSM items, scored from 1 to 5 ( 1 for 'strongly disagree' to 5 for 'strongly agree') for positive items and from 5 to 1 for the reversed items. The items used in this study referred to Perry's subscales of PSM dimension and measures (Perry, 1996). While service quality in this study referred to Dwiyanto et.al. (2002) indicators consisting of: 1) Immediacy in service delivery; 2) Timeliness of services; 3) Ease in the service process; 4) Funding reasonable in the service process; 5) easiness in communication access; 6) Readiness of employees; 7) Justice in providing services; and 8) public satisfaction with the service.

The target population for this study focused on all civil servants in local government institutions in West Sumatra. Number of public servants who served in West Sumatra province based on data from the Central Bureau of Statistics in 2014 is around 139,020 employees. The sample for this study were determined through disproportional stratified random sampling. It consisted of employees from some institutions of public sector in some regencies in West Sumatera. From the number of 1,500 questionnaires distributed in this study, it is only 1,270 respondents of public servants who give feedback.

Data in this study were collected through questionnaires with a closed set of five alternative answers using the Likert scale. Data analyzing in this study used quantitative analysis. The data in this study was also double entered to check for errors and analysed with multiple regression.

\section{Finding and Discussion}

The main hypothesis of this study stated that there is a significant influence of PSM on service quality of civil servants in West Sumatra, Indonesia. After the coefficient of determination and the adjusted coefficient of determination have calculated, the regression statistic through ENTER method is used in this study. As can be seen in Table 2, the regression analysis indicates the relationship between the variables. Since the computed significance level is 0.000 and less than 0.5 , with a $95 \%$ confidence level, then the null hypothesis is rejected and the research hypothesis is confirmed. In other words, there is a significant influence of the variables of PSM on service quality among civil servants.

Almost all of studies on PSM in developed countries, as conducted by Perry and Wise (1990), Perry (1996 and 2000), Choi (2001), Andersen (2012), Cho and Perry (2012), Andersen, Heinesen, and Pedersen (2014), Van Loon, Vandenabeele, and Leisink (2015), Chen and Hsieh (2015), and others, generally found that there was a significant influence of PSM on job performance among civil servants. This means that the PSM is also assumed to have influence on service quality. 
Based on various research findings, the main objective of this study is to determine the influence of PSM on service quality of civil servants in West Sumatra, Indonesia. To meet this objective the main hypothesis of this study stated that: There is a significant influence of PSM on service quality of civil servants in West Sumatra, Indonesia. Testing on this hypothesis has been made using multiple regression tests. The result is as seen in Table 1 below.

Tabel 1: Influence of PSM on service quality of civil servants

\begin{tabular}{llllll}
\hline Model & $\mathrm{R}$ & $\mathrm{R}$ Square & Adjusted R Square & $\begin{array}{l}\text { Std. Error of the } \\
\text { Estimate }\end{array}$ & Durbin-Watson \\
\hline 1 & .163 & .027 & .026 & .56262 & 1.106 \\
\hline
\end{tabular}

The results of data analysis using multiple regression shows that PSM has weak influence and little contribution on service quality, with the correlation coefficient of 0.163 . This shows a quite far relation (far from 1 ) on service quality. The direction of positive relation (no negative sign in figure 0.163 ) shows the higher the PSM level the higher service quality of the civil servants. Likewise, the lower the PSM level the lower service quality of the civil servants.

In addition, based on the table 1 (Adjusted R Square $=.026$ ), PSM contributed only 2.6 percent on service quality. It means that PSM has only very little contribution on service quality (only $2.6 \%$ ). In other words, it could be stated that $2.6 \%$ of the variation of service quality can be explained by the PSM. Meanwhile, the rest $(100 \%-2.6 \%=97.4 \%)$ could be influenced by other reasons that have not been revealed in this study.

Furthermore, the level of influence significance of the output (measured by probability) gives the figure of 0.000 or practically 0 , as seen in Table 2. Because the probability is far below 0.05 , then the influence of PSM on service quality is very real and could be trusted up to $100 \%$ or even more.

Table 2: Significance of PSM influence on service quality

\begin{tabular}{lllllll}
\hline Model & & Sum of Squares & $\mathrm{df}$ & Mean Square & $\mathrm{F}$ & Sig. \\
\hline 1 & Regression & 10.989 & 1 & 10.989 & 34.716 & $.000^{\mathrm{a}}$ \\
& Residual & 401.376 & 1268 & .317 & & \\
& Total & 228.334 & 1269 & & & \\
\hline
\end{tabular}

The present study aimed to investigate the influence of PSM on service quality of civil servants in West Sumatra, Indonesia. Generally, the studies related to influence of PSM on job performance (including service quality) demonstrated a significant and strong relationship (influence) among the variables. The findings of the current research also illustrated a significant influence of PSM on service quality. However, PSM only contributed very little and weak to service quality.

Furthermore, the results of this study is of course in line with almost all of studies on PSM as conducted by Perry and Wise (1990), Perry (1996 and 2000), Choi (2001), Andersen, et.al. (2012), Cho and Perry (2012), Andersen, Heinesen, and Pedersen (2014), Van Loon, Vandenabeele, and Leisink (2015), Chen and Hsieh (2015), and others, which found that there was a significant influence of PSM on job performance or service quality among civil servants. However the present study demonstrated that the influence of PSM on service quality is very weak (only $2.6 \%$ ).

Research findings on PSM in many developed countries often found something different compared to the research findings in the third world countries. Therefore, it is understandable that the current findings quite differ in many ways compared to the findings on the same case in the developed countries. Studies from several developed countries in the West, such as the United States, Britain, Sweden, Australia, and others, including findings about the level of PSM in Korea, as has been conducted by Choi (2001), found that in general PSM has has strong influence on job performance or service quality of civil servants.

Most of motivation scholars have argued that intrinsic motivation, including PSM, is an important driver of employee attitudes (Cho and Perry, 2012). Based on this, it is expected that with higher level of public service motivation, public servants will perform better and address good service quality in their task to serve citizens. Nevertheles, Van Loon (2015) argued that although empirical studies have found a positive relationship between public service motivation (PSM) and individual performance, the relationship may be differed in any contexts. 
In addition, Houston (2000) and Willem et.al (2007) also found that the employees in the public sector puts a higher value on intrinsic rewards of work in the form of work performance (service quality), good social relations, and self-esteem of the rewards that are extrinsic, such as financial payments, promotions, career advancement, job security, status and prestige. This means that the employees at the government organizations or positions more motivated by their awareness to the community and a desire to serve the public interest and less concerned with rewards that are extrinsic to purely personal interests. Based on this, it is more likely that civil servants will perform better and address good service quality in their tasks to serve public interest.

However, most of general conclusions which states that "PSM has strong influence on job performance or service quality", as often founded by researchers in the West or other developed countries, could not be applied to the public servants in West Sumatra. This also shows that it appears to assume that Choi's finding (2001), based on his study among civil servants in Korea, does not generally occur in any area of the country. As stated above, Choi was of the opinion that PSM is a common and important basis for public servants, and the implications of the PSM on the employee behavior in developed countries in the West, such as the United States, also occurs among the civil servants in Korea. Thus Choi viewed that the theory of PSM might occur in cross-cultural (cross-culturally viable). However, this assumtion does not occur in the case of PSM and service quality of civil servants in West Sumatra.

Thus in general, it is understandable that the theories related to the study of the PSM in various public sectors in developed countries, especially in the United States, Australia and other developed countries, could not be generalized to all contexts, especially for public servants in developing or third world countries that have characteristics of a social, cultural, economic, ideological, religious, and other values which might be different from those of in the West. As a result, these differences may lead to the different situation and influences of PSM on service quality of civil servants in different places (countries).

\section{Conclusion}

More than three decades, scholarly interest in Public Service Motivation (PSM) has grown remarkably. Theories and findings on PSM have also been debated in various studies in some developed countries more than three decades. However, those studies have not managed to get a strong theory to explain these PSM cases among the employees. The findings still need new evidences based on studies in various contexts and regions of the any countries so that they can find a stronger theory at one time.

Most of PSM studies conducted in developed countries so far, especially in the West, generally found that the PSM has very strong influences on service quality or job performance. The higher level of PSM the higher service quality performed by civil servants. In addition, several findings also imply that the level of the PSM and its influence on service quality of civil public servants in developed countries in the West is also assumed to exist among public servants in any area of the country. A few scholars argued that the theory of PSM might be cross-culturally viable. But, of course, this conclusion is not entirely true and does not occur in the case of PSM among public servants in West Sumatra.

The findings of this study have several implications for the theory, particularly to the development of public administration, especially further to the matters related to the administration of public services and the influence of PSM on service quality of civil servants. This means that the results of this study can contribute ideas and more enriching knowledge related to public administration and public service motivation.

The findings of this study clearly show that the theory of PSM can not be generally comprehended and concluded as a valid theory. As to understand so far, the theories of PSM in Western countries or other developed countries almost generally view that the theory of PSM might be cross-culturally viable. However, this assumtion could not be aplied in the case of PSM among civil servants in West Sumatra. PSM in the different areas and conditions will naturally show different things as well. The studies of PSM so far might have assumed that the level of PSM tends to have strong influence on service quality of civil servants. However, it seems that these studies did not take into account the existence of the aspects of culture, ideology, economic level of a community, and other unique characteristics of the civil servants. In other words it can be assumed that the theory of PSM is not cross-culturally viable as we knew so far.

\section{Note}

This article is Abstracted from the results of study funded by the Directorate General of Higher Education, Ministry of National Education of Indonesia in 2014.

\section{References}


[1] Andersen, Lotte Bogh (2012) Attracting public service motivated employees: how to design compensation packages. International Review of Administrative Sciences December 201278 (4).

[2] Andersen, Lotte Bogh, Eskil Heinesen and Lene Holm Pedersen (2014) How does public service motivation among teachers affect student performance in schools? Journal of Public Administration Research and Theory July 2014 24: 651-671.

[3] Andersen, Lotte Bogh, Thomas Pallesen and Lene Holm Pedersen (2011) Does ownership matter? public service motivation among physiotherapists in the private and public sectors in Denmark. Review of Public Personnel Administration March 201131 (1).

[4] Blair, Williams and James C Garand (1995) Are bureaucrats different? democratic values, political tolerance, and support for the political system among government employees and other citizens. In: Annual Meeting of the American Political Science Association August 31-September 3, Chicago.

[5] Bradley E. Wright and Adam M. Grant (2010) "Unanswered Questions about Public Service Motivation: Designing Research to Address Key Issues of Emergence and Effects". Public Administration Review. September - October 2010, 691-700

[6] Brewer, GA (2003) Building social capital: attitudes and behavior of public servants. Journal of Public Administration Research and Theory 13 (1): 5-26.

[7] Brewer, GA and Selden SC (1998) Whistle blowers in the federal civil service: new evidence of public service ethic. Journal of Public Administration Research and Theory 8 (3):413-39.

[8] Chen, Chung-An and Chih-Wei Hsieh (2015) Knowledge sharing motivation in the public sector: the role of public service motivation. International Review of Administrative Sciences December 2015 81: 812-832.

[9] Cho, Yoon Jik and James L Perry (2012) Intrinsic motivation and employee attitudes: role of managerial trustworthiness, goal directedness, and extrinsic reward expectancy. Review of Public Personnel Administration December 201232 (4).

[10] Choi, Young Joon (2001) A Study of Public Service Motivation: The Korean Experience. Ph.D. Dissertation, University of Idaho.

[11] Clerkin, Richard M and Jerrel D Coggburn (2012) The dimensions of public service motivation and sector work preferences. Review of Public Personnel Administration, September 201232 (3).

[12] Conway, M Margareth (2000) Political Participation in the United States. $3^{\text {rd }}$ Ed. Washington, DC: CQ Press.

[13] Dwiyanto, A., et.al. (2002) Public Bureaucracy Reform in Indonesia (Reformasi Birokrasi Publik di Indonesia). Yogyakarta: PSKK UGM.

[14] Emanuel Camilleri (2007) "Antecedents Affecting Public Service Motivation". Personnel Review, 2007, Vol. 36, Issue: 3 pp. $356-377$.

[15] Ertas, Nevbahar (2014) Public service motivation theory and voluntary organizations: do government employees volunteer more?. Nonprofit and Voluntary Sector Quarterly, April 201443 (2).

[16] Houston, David J (2000) Public service motivation: a multivariat test. Journal of Public Administration Research and Theory (J-PART), 200010 (4): 713-727.

[17] Kjeldsen, Anne Mette and Christian Botcher Jacobsen (2013) Public service motivation and employment sector: attraction or socialization?. Journal of Public Administration Research and Theory October 2013 23: 899-926.

[18] Leonard Bright (2011) "Does Public Service Motivation Affect the Occupation Choices of Public Employees?" Public Personnel Management Volume 40 No. 1 Spring 2011; 11-23

[19] Lewis, B.R. \& Mitchell, V.W. (1990) "Defining and measuring the quality of customer service," Marketing Intelligence and Planning, vol. 8(6), p.11-17.

[20] Moynihan, D.P. and S.K. Pandey (2007) "The Role of Organizations in Fostering Public Service Motivation" in Public Administration Review 67 (1): 40 - 53

[21] Nyeck, S., Morales, M., Ladhari, R., \& Pons, F. (2002) "10 years of service quality measurement: reviewing the use of the SERVQUAL instrument." Cuadernos de Difusion, 7(13), 101-107. Retrieved July 8, 2007, from EBSCOhost database.

[22] Pandey, Sanjay K. and Edmund C. Stazyk (2008) "Antecedents and Correlates of Public Service Motivation" in James Perry and Annie Hondeghem: Motivation in Public Management. The Call of Public Service. New York: Oxford University Press.

[23] Parasuraman, A., Zeithaml, V. and Berry, L.L. (1985) A conceptual model of service quality and its implications for future research, The Journal of Marketing, p. 41-50.

[24] Parasuraman, A., Zeithaml, Valerie A. \& Berry, Leonard L. (1988) "SERVQUAL: a multiple-item scale for 
measuring consumer perceptions of service quality," Journal of Retailing, vol. 64(1), p. 12-40

[25] Perry, James L (1996) Measuring public service motivation: an assessment of construct reliability and validity. Journal of Public Administration Research and Theory (J-PART) 6 (1): 5-23

[26] Perry, James $L$ (2000) Bringing society in: toward a theory of public service motivation. Journal of Public Administration Research and Theory April 2000: 471-488.

[27] Perry, James L and Lois Recascino Wise (1990) The motivational bases of public service. Public Administration Review May/June 1990 50:367-373.

[28] Perry, James L. and Annie Hondeghem (2008) Motivation in Public Management. The Call of Public Service. New York: Oxford University Press.

[29] Rainey, Hal G (1982) Reward references among public and private managers: in search of the service ethic. American Review of Public Administration 1982 16: 288-302.

[30] Rainey, Hal G (1997) Understanding and Managing Public Organizations. $2^{\text {nd }}$ ed. San Fransisco, CA: JosseyBass Publishers.

[31] Rainey, Hal G and Paula Steinbauer (1999) Galloping elephant: developing elements of theory of effective government organizations. Journal of Public Administration Research and Theory January 1999 9 (1): 1-32.

[32] Rose, Roger $P$ (2013) Preferences for careers in public work: examining the government-nonprofit divide among undergraduates through public service motivation. The American Review of Public Administration July 2013 43: 416-437.

[33] Schott, Carina, Daphne D van Cleef and Trui Steen (2015) What does it mean and imply to be public service motivated? The American Review of Public Administration November 201545 (6).

[34] Steijn, B. (2008) "Person-environment fit and public service motivation", International Public Management Journal, 11 (1), pp. 13-27.

[35] Taylor, Jeannette and Ranald Taylor (2011) Working hard for more money or working hard to make a difference? Efficiency wages, public service motivation, and effort. Review of Public Personnel Administration March 2011 31 (1).

[36] Van De Walle, Steven, Bram Steijn and Sebastian Jilke (2015) Extrinsic motivation, PSM and labour market characteristics: a multilevel model of public sector employment preference in 26 countries. International Review of Administrative Sciences 201581 (4): 833-855.

[37] Van Loon, Nina Mari (2015) Does context matter for the type of performance-related behavior of public service motivated employees?. Review of Public Personnel Administration, June 2015.

[38] Van Loon, Nina Mari, Wouter Vandenabeele and Peter Leisink (2015) Clarifying the relationship between public service motivation and in-role and extra-role behaviors: the relative contributions of person-job and personorganization fit. The American Review of Public Administration, December 2015.

[39] Vandenabeele, Wouter (2007) "Toward a Public Administration Theory of Public Service Motivation: An Institutional Approach", Public Management Review, 9 (4), pp. 545-556.

[40] Willem, Annick, ANS de Vos and Marc Buelens (2007) Differences between private and public sector employees' psychological contracts. Working paper. Belgium: Ghent University, Faculty of Economics and Business Administration, Department Management and Entrepreneurship, Tweekerkenstraat 2, 9000.

[41] Zeithaml, Parasuraman \& Berry, "Delivering Quality Service; Balancing Customer Perceptions and Expectations," Free Press, 1990.

[42] Zeithaml, Valerie A. \& Bitner, Mary J. (1996) Services Marketing, McGraw-Hill, New York, N.Y. 